\title{
The predictor role of gratitude and psychological vulnerability on forgiveness
}

İlbay, Azmi Bayram

Bülent Ecevit University, Turkey (azmiilbay@gmail.com)

Sarıçam, Hakan $\$

Dumlupinar University, Turkey (hakan.saricam@dpu.edu.tr, hakansaricam@gmail.com)

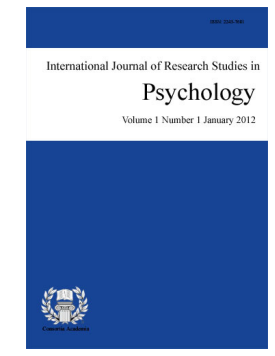

ISSN: $2243-7681$ Online ISSN: 2243-769X

OPEN ACCESS

\section{Abstract}

The aim of this research was to investigate the relationships among forgiveness, gratitude, and psychological vulnerability. 416 university students completed the Trait Forgiveness Scale, Gratitude Scale and Psychological Vulnerability Scale. The Participants' degree programs were psychological counselling and guidance, primary education, special education, early childhood education, science education, and child development. Relationships between the three constructs were analyzed through The Pearson Product Moment Correlation Coefficient. Structural Equation Modelling (SEM) was used to examine the extent to which forgiveness was predicted by gratitude and psychological vulnerability. Results showed that there were significant relationships between forgiveness, gratitude, and psychological vulnerability. Indices of Structural Equation Modelling (SEM) indicated that forgiveness was strongly predicted by gratitude and psychological vulnerability. The findings highlight the importance of gratitude and psychological vulnerability in the level of forgiveness.

Keywords: forgiveness; gratitude; psychological vulnerability 


\section{The predictor role of gratitude and psychological vulnerability on forgiveness}

\section{Introduction}

In psychology, positive potentiality and virtuous attitudes of individuals and their characteristics, which contribute to their improvement and strength and support their feeling god themselves, are now being studied closely. Forgiveness is one of the concepts among them (Gable \& Haidt, 2005; Elliot, 2010; Linley \& Kauffman, 2007; Seligman, 2002). Being a forgiver is a process of exhibiting positive feelings toward someone by an individual's abandoning his negative feelings for the person who hurts him (Thoresen, Harris, \& Luskin, 2000; Madsen, Gygi, Hammond, \& Plowman, 2009). It increases the positive feelings, thoughts, and attitudes of the individual (McCullough, 2008). Forgiveness is a process, which the individual achieves at the level of personality and interpersonality; however, those levels are not independent of each other (Ergüner-Tekinalp \& Terzi, 2012; Riek, 2010). Forgiveness is harboring good will by abandoning all the negative feelings toward the guilty person after the act of offense (McCullough \& Witvliet, 2001).

Different approaches in different fields related to the concept of forgiveness come into question (Legaree, Turner, \& Lollis, 2007). The concept was first touched upon in theology and philosophy, then in psychology; also, it has been mentioned in social psychological studies (Koutsos, Wertheim, \& Kornblum, 2008). Forgiveness in the sense of philosophy is a virtuous attitude (Emmons \& Paloutzian, 2003). Forgiveness in terms of psychology is considered a manner of reaction initiating high-level moral behavior and the improvement process of healthy behavior (Hepp-Dax, 1996). Forgiveness is one of the transcendentalist behaviors of the individual, which results in positive outcomes (Berry, Worthington, O'Connor, Parrot, \& Wade, 2005).

The act of forgiveness can be manifested in different forms such as self-forgiveness, forgiving someone else, ethnic groups' forgiving each other, and international forgiveness (Hepp-Dax, 1996). Self-forgiveness and forgiving someone else are two different situations (Macaskill, 2012). Sometimes, the individual may display regret, self-accusatory attitudes and negative reactions towards himself (Strelan, 2007). In such a case, decreasing the effects of the feelings of revenge, rage, and enmity, the sense of forgiveness could be brought about as a result of a process achieved by standing corrected and taking the responsibility (Hall \& Fincham, 2005). Reconciliation at the cognitive-emotional-behavioral level is required for self-forgiveness in terms of psychological health. As self-forgiveness is compared to interpersonal forgiveness, the fact that psychological vulnerabilities of self-forgiveness are more therapeutic has a significant, determinant role (Delamater \& Myers, 2011). Self-forgiveness should not be achieved for the mental health not to be damaged anymore (Taysi, 2007). Nevertheless, forgiving increases individual's well-being no matter how it is displayed (McCullough \& Witvliet, 2002).

There are cognitive (Thompson \& Snyder, 2003), emotional (Worthington \& Wade, 1999), cognitive-emotional-behavioral (Enright \& Fitzgibbons, 2000) aspects of forgiving. It starts with cognitive-based evaluations. After that, it turns into decision-making in light of those data. The individual, at this stage, reveals his emotional awareness while trying to forgive. In the last phase, the process finishes with the internalization by reconciling at cognitive-emotional-behavioral levels (Enright \& Fitzgibbons, 2000). Besides, forgiveness should be one of the strategies to be added to the process of psychological consultation which contributes towards individual's healing and bringing out his potentiality (Alex, Thoresen, \& Lopez, 2007).

Forgiving is one of the beneficial characteristics. If forgiving includes individual's behavior of taking responsibility related to his guilt by struggling on making up for his own mistake, it provides overcoming and healing. It has been determined that personality traits such as empathy, positive self-esteem, and forgiving have corrective power over the perpetrator, sufferer, and the vulnerable (Woodyatt \& Wenzel, 2013). In order for forgiving to constitute healing in terms of psychological health, it should be achieved through internalizations 
The predictor role of gratitude and psychological vulnerability on forgiveness

(Auerbach, 2005). Self-forgiveness is related to psychological healthiness, endurance and satisfaction with life (Macaskill, 2012). Reaching real and permanent forgiving is only possible through individual's avoidance of rumination (reverie) (Sarıçam \& Akın, 2013). During the process of forgiveness, a person is provided to find the opportunity of reorganizing his self with the effects of positive feelings such as self-value and self-esteem (McLernon, Cairns, Hewstone, \& Smith, 2004).

\subsection{Gratitude}

First come the personal characteristics; second, if the individual has any life goals; finally, the effects of variables related to demographic qualities are mentioned among the variables of individual's positive psychological qualities, which affect subjective well-being. Gratitude is one of the concepts taking part in the content of personal characteristics among positive psychological qualities (Lyubomirsky, Sheldon, \& Schkade, 2005). Gratitude has positive relations with all the variables of subjective well-being (McCullough, Emmons, \& Tsang, 2002). Gratitude is one of the qualities required to be possessed and improved in order for the individual to maintain his life according to positive psychological criteria (Miller \& Nickerson, 2007).

Even though the concept of gratitude is a driving feeling that forces the individual to repay with a sense of indebtedness related to someone who contributes the individual, it is a kind of reaction concerned with positive feelings which create positive sensation (Datu, 2013; Goei \& Boster, 2005; McCullough, Kilpatric, Emmons, \& Larson, 2001). It is a personal tendency and a reaction given by individual's sense of appreciation towards benefit or contribution availed from someone else. The individual may sometimes develop feelings of gratitude and appreciation at a metaphysical level, as a matter of his own beliefs, in a case when he feels positive (Froh, Kashdan, Ozimkowski, \& Miller, 2009; Emmons, McCullough, \& Tsang, 2007). It is a sensation in a tendency of responding toward an attitude about giving free of bias (McCullough, Emmons, \& Tsang, 2002). Although gratitude is a behavior with has social sources, it increases psychological well-being, improves optimistic behavior, and strengthens the sense of commitment (Fredrickson, 2004). It is seen that as gratitude increases, in contrast to vulnerability, endurance improves, depression and concern decrease with many positive sensations (McCullough et al., 2002; Emmons, McCullough, 2003; Watkins, Woodward, Stone, \& Kolts, 2003; Seligman, Steen, Park, \& Peterson, 2005; Kashdan, Uswatte, \& Julian, 2006; Wood, Joseph, \& Linley, 2007).

\subsection{Psychological vulnerability}

Self-esteem is one of the other factors that provides psychological well-being (Baumeister, Campbell, Krueger, \& Vohs, 2003; Neff, 2011). The quality of self-esteem (whether it is reliable or vulnerable), its quantity (whether it is high or low) are different from each other (Southall, \& Roberts, 2002). For instance, the self-esteem of narcissistic people both can be high or vulnerable (Donnellan, Trzesniewski, Robins, Moffitt, \& Caspi, 2005). On the other hand, although humble people's self-esteem is low, the individual may not have psychological vulnerability (Tracy, Cheng, Robins, \& Trzesniewski, 2009). As the concepts of self-esteem and psychological well-being are directly related to vulnerability, the concept of psychological vulnerability is among the variables of this study.

Vulnerability is a reaction peculiar to non-durability toward psychological disorders, and toward an individual's mood in which there is a bête noir stimulus (Ingram \& Price, 2010). It is a form of reaction closely related to an individual's cognitive and interpersonal variables (Monreo \& Simons, 1991). It is high affinity developed by the individual toward negative outcomes (Wright \& Masten, 2006). The first confrontation of the individual with him or her vulnerability occurs when he or she experience a traumatic incident, has fears, insolubility, incapability, despair in his daily lives. Traumatic stress makes the individual experience vulnerability. This vulnerability causes him or her to lose the meaning of life in company with encountering an unusual incident (Stamm, 1995).

Increases or decreases in self-value or self-esteem may constitute a sense of vulnerability. The state of 
anxiety related to the loss of positive sensation level in the case of increase may push the individual toward vulnerability. In the case of decrease, however, the individual's losses, deficiency, inadequateness, and insignificance may cause vulnerability. In addition, there also appears individual's immaturity besides his psychological vulnerability and his accusatory attitudes during his tendency towards depression (Black \& Sheline, 1997). It is generally seen that symptoms arising as a result of depression and increase in those symptoms are usually accompanied by psychological vulnerability (Crocker, 2002). Personal, cognitive, and environmental factors may cause an increase in individual's vulnerability. Vulnerabilities should not be seen as the major cause of mental disorders but more of a factor which poses a risk (Gudjonsson, 2010).

Vulnerability has a psychological, social and physical quality. The vulnerable individual is an easy target against detrimental effects (Scanlon \& Lee, 2007). Psychological vulnerability is affected by the patterns in its cognitive form. When these cognitive patterns reflect upon the interpersonal relationships of the individual, they affect the psychological and physical well-being of the individual. Addiction, shame, perfectionism, cognitive biased patterns are the triggering factors of vulnerability (Sinclair \& Watson, 1999). In addition, vulnerability could be associated with genetic factors as well. When its psychological aspect is touched upon, the source and level of vulnerability hinges on the individual's non-functional learning (Ingram \& Luxton, 2006). Individual's non-functional learning triggers many psychological disorders especially depression (Monrain \& Blackburn, 2005). Vulnerability is related to the structure of an individual's personality. Individual's vulnerability causes a developed sensibility, which will carry him to psychological disorders (Gökçakan \& Gökçakan, 2005). Individual's vulnerability levels are in a positive relationship with sensibilities related to being rejected (Erözkan, 2004).

Psychological vulnerability also includes weak coping behavior which appears as a result of emotional weakness. An individual's having a positive mood will result in much positive psychological behavior (Depue, Morrone, \& Strupinsky, 2005). Therapeutic processes, which contribute to the enhancement of an individual's positive mood, have contributions that decrease the vulnerability toward psychological disorders (Gilbert \& Procter, 2006; Mayhew \& Gilbert, 2008). It has been stated that individual's temper generally appearing at an early age, his irregular life, eating and sleeping habits, negative mood settling as a result of sleeping habits may cause psychological vulnerability (Pearce, 1992).

A relationship exists between psychological vulnerability, age, and sex. When older women are compared with younger male individuals, it has been determined that the young male individuals' vulnerability levels are lower (Hoshi, 2008). Women display negative moods more easily. In this case, their inadequacy upon coping abilities may have an improving effect on their vulnerability (Kessler \& McLoad, 1984). Vulnerability levels of the teenagers who are not supported by their parents are increasing, and their self-esteem is decreasing (Erözkan, 2009). When teenagers are considered in terms of interpersonal relationships, factors such as being admired, fears of disappointment, concern for being rejected could be effective upon teenager's mood, and sadness and vulnerability may become prominent (Silvers, Mcrae, Gabrieli, Gross, Remy et al., 2012).

\subsection{Present study}

In the light of the reciprocal forgiveness has positive relationships between well-being (McCullough \& Witvliet, 2002; Tse \& Yip, 2009), mercy (MacLachlan, 2012), empathy (Davis \& Gold, 2011; Fourie, Gobodo-Madikizela, \& Stein, 2013; Rungduin \& Rungduin, 2013) and self-esteem (Cardi, Milich, Harris, \& Kearns, 2007), whereas negative relationships between depressive symptoms (Nsamenang, Webb, Cukrowicz, \& Hirsch, 2013; Tse \& Yip, 2009), stress (Carson et al., 2005), rumination (Lucas, Young, Zhdanova, \& Alexander, 2010) which have been shown by previous studies. Also, gratitude is a key concept for psychological well-being (Wood, Joseph, \& Maltby, 2009) and life satisfaction (McCullough, Emmons, \& Tsang, 2002), contrary it is associated with depression. Besides, low psychological vulnerability is related positively not only to stress, suicide but also negatively self-esteem. To sum up, since these three structures are allied with positive psychology and subjective well-being, forgiveness may contribute to the association with gratitude and 
psychological vulnerability. As far as our knowledge, there are no studies about relations between gratitude, psychological vulnerability, and forgiveness. The basic purpose of this study was to examine the gratitude, psychological vulnerability as related to forgiveness. Hence, it was hypothesized in this study that as gratitude increases, forgiveness may increase or vice versa, and that psychological vulnerability may decrease. This hypothesized model was given Figure 1.

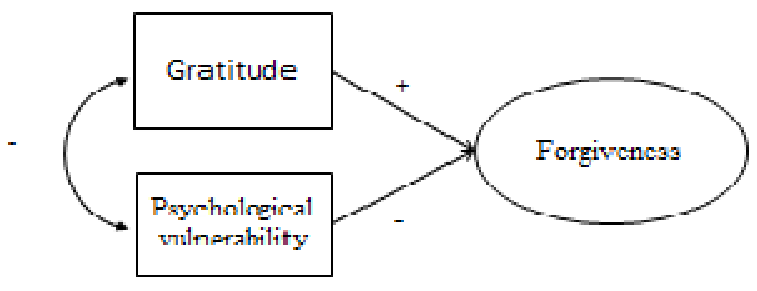

Figure 1. Hypothesized model of relations between forgiveness, gratitude and psychological vulnerability

\section{Method}

\subsection{Participants}

The study group comprised 416 of which (206 (49.6\%) were male and 210 female (50.4\%) university students from Sakarya University. The departments of these preservice teachers were psychological counseling and guidance $(n=77)$, science education $(n=49)$, primary education $(n=52)$, early childhood education $(n=59)$, special education $(n=55)$ and child development $(n=124)$. Of the participants, 108 students $(26 \%)$ were freshmen, $104(25 \%)$ were sophomores, $104(25 \%)$ were juniors and $100(24 \%)$ were seniors students. Their ages ranged from 17 to 24 , and the mean age of the participants was 20.1 years.

\subsection{Instruments}

Trait Forgiveness Scale (Berry et al., 2001): The scale consists of ten items (e.g., I can forgive a friend for almost anything) and each items ranging from 1 (strongly disagree) to 5 (strongly agree). Yield total scores from 10 to 50 where higher scores indicate more forgiveness level. Turkish adaptation of this scale had been done by Sarıçam and Akın (2013). Kaiser-Meyer-Olkin (KMO) measure of sampling adequacy of .67, and a significant result on Bartlett's test of Sphericity $\chi^{2}=518,353(p<.001, \mathrm{df}=120)$. Results confirmatory factor analyses demonstrated that 10 items yielded one factors as original form and that the one-dimensional model was well fit $\left(\chi^{2}=106.47, \mathrm{df}=32, \mathrm{RMSEA}=.077, \mathrm{CFI}=.89, \mathrm{GFI}=.95, \mathrm{AGFI}=.91, \mathrm{SRMR}=.062\right)$. Factor loadings ranged from .52 to .77 . Cronbach alpha internal consistency coefficient was found as .67. In the concurrent validity, the Trait Forgiveness Scale was associated with the Heartland Forgiveness Scale $(r=.84)$. Test-retest reliability coefficient was .88. Corrected item-total correlations ranged from .37 to .48. Cronbach alpha internal consistency coefficient was found as $.86(\mathrm{~N}=416)$ in this study. This scale is valid and reliable instrument according to statistic criteria in psychology researches (Howitt \& Cramer, 2014).

Gratitude Questionnaire (GQ; McCullough, Emmons, \& Tsang, 2002): The scale consists of six items (e.g., I have so much in life to be thankful for) and each items ranging from 1 (strongly disagree) to 7 (strongly agree). Turkish adaptation of this scale had been made by Yüksel and Oguz Duran (2012). The results of confirmatory factor analysis indicated that the five items model was well fit and Chi-Square value $\left(\chi^{2}=76.25, \mathrm{df}=5\right)$ which was calculated for the adaptation of the model was found to be significant. The model had perfect fit index values $(\mathrm{GFI}=0.97, \mathrm{CFI}=.94, \mathrm{AGFI}=0.90, \mathrm{SRMR}=0.04, \mathrm{RMSEA}=0.10)$. Factor loadings ranged from .38 to .89 . The Cronbach alpha coefficient of the questionnaire was .77 and the corrected item-total correlations of GQ ranged from .59 to .83 . The four weeks test-retest variability of the GQ, based on a sub-sample $(n=51)$ of the total sample was $.66(p<.01)$. In this study, Cronbach alpha internal consistency coefficient was found as .82 $(\mathrm{N}=416)$. This instrument is valid and reliable scale according to statistic criteria in social sciences researches 
İlbay, A. B., \& Sarıçam, H.

(Stevens, 2009).

Psychological Vulnerability Scale (Sinclair \& Wallston, 1999). The scale consists of six items (e.g., If I don't achieve my goals, I feel like a failure as a person) and each items ranging from 1 (Does not describe me at all) to 5 (Describes me at all). Yield total scores from 6 to 30 where higher scores indicate more psychological vulnerability level. Turkish adaptation of this scale had been done by Akın and Eker. The results of confirmatory factor analysis indicated that the model was well fit and Chi-Square value $\left(\chi^{2}=7.82, \mathrm{df}=9, p=0.55272\right)$ which was calculated for the adaptation of the model was found to be significant. The goodness of fit index values of the model were $\mathrm{RMSEA}=.000, \mathrm{NFI}=.97, \mathrm{CFI}=1.00, \mathrm{GFI}=.99$, AGFI $=.98, \mathrm{RFI}=.95$, and $\mathrm{SRMR}=.025$. Factor loadings ranged from .46 to .69 . The Cronbach alpha coefficient of the questionnaire was .75 and the corrected item-total correlations of PVS ranged from .26 to .44 (Quoted in Sarıçam, 2015). Cronbach alpha internal consistency coefficient was found as .79 $(\mathrm{N}=416)$ in this study. This measure is valid and reliable scale according to statistic criteria in behavioral sciences researches (Tabachnick \& Fidell, 2013).

\subsection{Procedure}

Permission for participation of students was obtained from related department managers. Participants' selection was based on simple random sampling and the participation was entirely voluntary. Prior to administration of the scales, all participants were informed about the purpose of the study. Design of this survey study is correlational research, is conducted when researchers want to explore "the extents to which two or more variables co-vary, that is, where changes in one variable are reflected in changes in the other" (Creswell, 2008, p. 358). Relationships among the three variables (forgiveness, gratitude and psychological vulnerability) were tested using Pearson Product Moment Correlation Coefficient at .01 probability level. Moreover, data were analyzed by means of confirmatory factor analysis and structural equation modelling (SEM) using the computer program. SEM is a statistical methodology that takes a confirmatory approach to the analysis (Byrne 2006). In this approach a hypothesized model of relations between variables is tested statistically to determine the extent to which it is consistent with the data, which is referred to as the goodness of fit. If the goodness of fit is adequate, it supports the plausibility of the relations among the variables. To assess the model fit, we used well-established indices such as CFI, IFI, TLI, and RMSEA as well as the chi-square test statistics. For the CFI, IFI, and TLI indices, values greater than .90 are typically considered acceptable and values greater than .95 indicate good fit to the data (Byrne 2006; Hu \& Bentler 1999). For well specified models, an RMSEA of .06 or less reflects a good fit (Hu \& Bentler 1999).

\section{Results}

\subsection{Correlations between forgiveness, gratitude and psychological vulnerability}

Table 1 shows the means, standard deviations, inter-correlations, and internal consistency coefficients of the variables used. Correlation analysis displayed that forgiveness related positively to gratitude $(r=.44)$ and psychological vulnerability $(r=.39)$.

\section{Table 1}

Correlations between forgiveness, gratitude and psychological vulnerability

\begin{tabular}{lccc}
\hline Variables & 1 & 2 & 3 \\
\hline 1. Forgiveness & 1 & & \\
2. Gratitude & $.44^{* *}$ & 1 & \\
3. Psychological vulnerability & $.39^{* *}$ & $.31^{*}$ & 1 \\
Mean & 35.43 & 30.31 & 18.36 \\
SD & 6.03 & 5.65 & 4.88 \\
Alpha $(\mathrm{N}=416)$ & .86 & .82 & .79 \\
\hline Note. $* *$ Correlation is significant at the .01 level (2-tailed). & & \\
*. Correlation is significant at the .05 level (1-tailed). & & \\
\end{tabular}




\subsection{SEM about teacher self-efficacy and teacher burnout}

One of the purposes of this study was to test whether forgiveness was predicted by gratitude and psychological vulnerability. The measurement model included three latent factors (forgiveness, gratitude and psychological vulnerability) and 21 observed variables. We tested a theoretical model with forgiveness as exogenous variable predicting gratitude and psychological vulnerability (Figure 2).

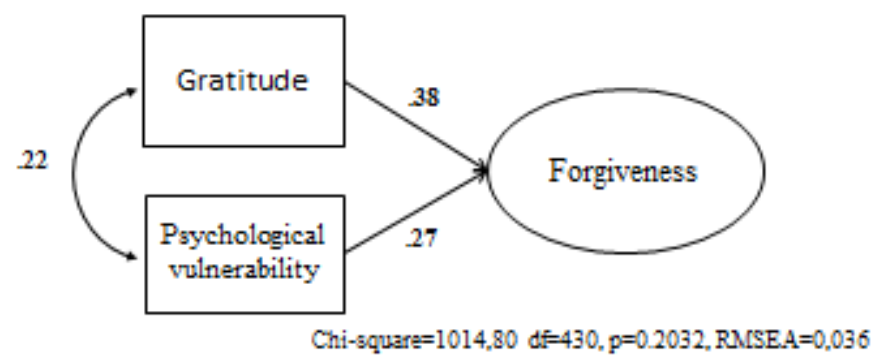

Figure 2. Structural equation model of relations between forgiveness, gratitude and psychological vulnerability

The model had acceptable fit to the data $\left(\chi^{2}(430, \mathrm{~N}=416)=1014.80, \mathrm{CFI}=.93, \mathrm{IFI}=.93\right.$, TLI $=.92$ and RMSEA =.036). Gratitude and psychological vulnerability were significantly related to the endogenous variable (forgiveness). The strongest predictor of forgiveness was gratitude $(\beta=.38)$, and also psychological vulnerability predicted forgiveness positively $(\beta=.27)$.

\section{Discussion}

The purpose of this study was to examine the relationships among forgiveness, gratitude, and psychological vulnerability. Findings have demonstrated that there are relationships among these variables. Also, the goodness of fit indexes of the path model indicated that the model was acceptable and correlations among measures were explained by the model ( $\mathrm{Hu} \&$ Bentler, 1999). For the first time, to our knowledge, we have examined the associations between gratitude, psychological vulnerability, and forgiveness.

First, as hypothesized, gratitude and psychological vulnerability had positively correlations to forgiveness. Previous studies of forgiveness and gratitude have focused on relations with positive structure such as well-being (Sheffield, 2003) and health (Thoresen et al., 2000), while studies of psychological vulnerability have tended to study relations with negative concepts like depression (e.g., Alloy \& Abramson, 2005; Ingram \& Price, 2010). Moreover, Sinclair and Wallston (1999) found negative relations between psychological vulnerability and adaptive concepts such as positive affect $(r=-.36)$ and life satisfaction $(r=-.39)$. Even though psychological vulnerability has negative characteristics, it is associated with forgiveness positively. Normally, it should be the opposite to this situation. However, sometimes psychological vulnerability may be defense and resilience mechanism (Karoly, 2010; Rafaeli \& Hiller, 2010). Namely, psychological vulnerability and forgiveness are self-regulation contrivance. Striking example, people can forgive others who are more vulnerable, because not to be sad or offended (Bono, McCullough, \& Root, 2008).

Second, gratitude and psychological vulnerability predicted forgiveness positively. Interpersonal conflicts may cause breakdowns of relationships. Instead of maintaining life with broken relationships, in order to put life in order, forgiving displays an elevated motivation and this case causes an increase in emotional commitment appearing as a result of tendencies such as gratitude (Worthington et al. 2005). In cases of individual's choice of forgiving, and forgiving occurring in the form of relationship, the person who is forgiven may react with a sense of gratitude. Being a forgiver in the pyramid model is explained by concepts such as remembering pain, showing empathy, presentation of forgiveness as a gift, inception of forgiving behavior, internalization of forgiving. When an individual realizes that he may hurt someone as well, feelings of mutual gratitude may appear (Worthington, 
1997, Çardak, 2013). When that person starts to realize that he can hurt someone just like a perpetrator, feelings of gratitude may appear (Worthington, 1997). Gratitude decreases individual's negative feelings, increases his positive feelings and strengthens the tendency of forgiving (Witvliet, Ludwig, \& Vander Laan, 2001; McCullough, Emmons, \& Tsang, 2002). Forgiving causes feelings of gratitude to develop as it constitutes the feeling of commitment in interpersonal relationships between both sides (Çardak, 2013). Among an individual's displayed behavior after a traumatic incident, come first the feelings of gratitude, mercy and forgiveness. The form of reaction displayed with gratitude may turn into individual's significant forms of coping and feel-good (Fredrickson, 2004). Individuals who have a sense of gratitude are the ones manifesting a tendency toward an attitude of forgiveness (McCullough et al., 2002). Hence, it appears that if people can enhance their forgiveness level, it is possible to ameliorate gratitude. Coherent this reasoning in this study gratitude was found positively related to forgiveness.

During the stage of forgiving when emotional awareness appears, empathy, mercy, emotional strengthening against the situation required to be forgiven, individual's experience of rage coming out with the gift of forgiveness given to the person needed to be forgiven, revenge, accusation tendency are going to decrease psychological vulnerability by turning into positive feelings at high levels (Bergin, 1991; North, 1987). During the resolution process of psychological vulnerability, being a forgiver means taking a significant step (Rye, 2005). A forgiver-individual's resistant and endurable situation eases the tendency of forgiveness (Kamat, Jones, \& Row, 2006). Most of the time, individuals would like to talk about their feelings of offense and vulnerabilities they experience, and they may have conflicting feelings about the subjects related to decisions of forgiveness (Wade \& Bailey, Shafer, 1998). Therefore, it appears that if people can enhance their forgiveness level, it is possible to enhance psychological vulnerability. Consistent with these results in this study psychological vulnerability was found positively related to forgiveness.

Results of this study also suggested that emotion regulation and quality of interpersonal relationship varies with conflict resolution and anger control educations. Some past researches showed same results like one significant study indicated that forgiveness is one of the determinant of gratitude (Fredrickson, 2004; Satici, Uysal, \& Akin, 2014), similarly some researches emphasized that there is a significant relation between psychological vulnerability and forgiveness (Breen, Kashdan, Lenser, \& Fincham, 2010; Huta \& Hawley, 2010). Findings from current research also reflected the correlation between psychological vulnerability and gratitude. This results show their coherence with previous studies, as Wood, Froh, and Geraghty (2009) denoted that grateful people were less angry and hostile, depressed, and emotionally vulnerable, experienced positive emotions more frequently. However, several limitations of the study should be noted in order to provide direction for future research. First, the analyses reported here should be regarded as exploratory because they concentrate upon model building rather than testing. As such, these findings could be subject to a sampling error and cannot be regarded as definitive until replicated with a fresh sample. Second, participants were university students and replication of this study for targeting other student populations should be made in order to generate a more solid relationship among constructs examined in this study, because generalization of the results is somewhat limited. Third, as correlational statistics were utilized, no definitive statements can be made about causality.

The present research reports that the gratitude and psychological vulnerability related to forgiveness significantly. Students high in gratitude are more likely to experience forgiveness. This study has implication for practice, psychologists, and educators. Firstly for practice, continuing studies could further our understanding of the significant predictors of forgiveness; without forgetting that more research is need to examine the antecedents of the forgiveness. Secondly for psychologists and educators, not being vulnerable gives predictions regarding that the individual will never experience a psychological problem, predictions have been expressed that in durability, individual's possibility of experiencing a problem is decreasing (Ingram \& Price, 2010). Finally for them, giving a support of self-management to the individuals who show immature, weak, vulnerable, accusatory, destructive, unreliable reactions and their developmental processes could be supported with contributions (Köse, 2003). 


\section{References}

Alex, H. S., Thoresen, C. E., \& Lopez, S. J. (2007). Integrating positive psychology into counseling: Why and (when appropriate) how. Journal of Counseling and Development, 85, 3-13. http://dx.doi.org/10.1002/j.1556-6678.2007.tb00438.x

Alloy, L. B., \& Abramson, L. Y. (2005). Cognitive vulnerability to depression. Encyclopedia of Cognitive Behavior Therapy, 3, 126-129. http://dx.doi.org/10.1007/0-306-48581-8_38

Auerbach, Y. (2005). Forgiveness and reconciliation: The religious dimension. Terrorism and Political Violence, 17, 469-485. http://dx.doi.org/10.1080/09546550590929174

Baumeister, R. F., Campbell, J. D., Krueger, J. I., \& Vohs, K. D. (2003). Does high self-esteem cause better performance, interpersonal success, happiness, or healthier lifestyles? Psychological Science in the Public Interest, 4, 1-44. http://dx.doi.org/10.1111/1529-1006.01431

Bergin, A. E. (1991). Values and religious issues in psychotherapy and mental health. American Psychologist, 46(4), 394-403. http://dx.doi.org/10.1037/0003-066X.46.4.394

Berry, J. W., Worthington, E. L., Jr., O’Connor, L., Parrott, L., \& Wade, N. G. (2001). Dispositional forgivingness: Development and construct validity of the Transgression Narrative Test of Forgivingness (TNTF). Personality and Social Psychology Bulletin, 27, 1277-1290. http://dx.doi.org/10.1177/01461672012710004

Black, K. J., \& Sheline, Y. L. (1997). Personality disorder scores improve elective pharmacotheraphy of depression. Journal of Affective Disorders, 43, 11-18. http://dx.doi.org/10.1016/S0165-0327(96)00101-2

Bono, G., McCullough, M. E., \& Root, L. M. (2008). Forgiveness, feeling connected to others, and well-being: Two longitudinal studies. Personality and Social Psychology Bulletin, 34, 182-195. http://dx.doi.org/10.1177/0146167207310025

Breen, W. E., Kashdan, T. D., Lenser, M. L., \& Fincham, F. D. (2010). Gratitude and forgiveness: Convergence and divergence on self-report and informant ratings. Personality and Individual Differences, 49, 932-937. http://dx.doi.org/10.1016/j.paid.2010.07.033

Byrne, B.M. (2006). Structural equation modeling with EQS: Basic concepts, applications and programming. Mahwah, NJ: Erlbaum.

Çardak, M. (2013). The relationship between forgiveness and humility: A case study for university students. Educational Research and Reviews, 8(8), 425-430.

Cardi, M., Milich, R., Harris, M. J., \& Kearns, E. (2007). Self-esteem moderates the response to forgiveness instructions among women with a history of victimization. Journal of Research in Personality, 41(4), 804-819. http://dx.doi.org/10.1016/j.jrp.2006.09.007

Carson, J. W., Keefe, F. J., Goli, V., Fras, A. M., Lynch, T. R., Thorp, S. R., \& Buechler, J. L. (2005). Forgiveness and chronic low back pain: A preliminary study examining the relationship of forgiveness to pain, anger, and psychological distress. The Journal of Pain, 6(2), 84-91. http://dx.doi.org/10.1016/j.jpain.2004.10.012

Creswell, J. (2008). Educational research: Planning, conducting, and evaluating quantitative and qualitative research. New Jersey: Pearson: Merrill Prentice Hall.

Crocker, J. (2002). Contingencies of self-worth: Implications for self-regulation and psychological vulnerability. Self and Identity, 1, 143-149. http://dx.doi.org/10.1080/152988602317319320

Datu, J. A. (2013). Gratitude-based group intervention manual for college student-athletes. International Journal of Research Studies in Psychology, 2(3), 81-88. http://dx.doi.org/10.5861/ijrsp.2013.294

Davis, J. R., \& Gold, G. J. (2011). An examination of emotional empathy, attributions of stability, and the link between perceived remorse and forgiveness. Personality and Individual Differences, 50(3), 392-397. http://dx.doi.org/10.1016/j.paid.2010.10.031

DeLamater, J. D., \& Myers, D. J. (2011). Social psychology. Belmont, CA: Wadsworth.

Depue, R. A., \& Morrone-Strupinsky, J. V. (2005). A neurobehavioral model of affiliative bonding: Implications for conceptualizing a human trait of affiliation. Behavioural and Brain Sciences, 28, 313-395. 
İlbay, A. B., \& Sarıçam, H.

http://dx.doi.org/10.1017/S0140525X05000063

Donnellan, M. B., Trzesniewski, K. H., Robins, R. W., Moffitt, T. E., \& Caspi, A. (2005). Low self-esteem is related to aggression, antisocial behavior, and delinquency. Psychological Science, 16, 328-335. http://dx.doi.org/10.1111/j.0956-7976.2005.01535.x

Elliott, J. C. (2010). Humility: Development and analysis of a scale. PhD diss., University of Tennessee, Knoxville.

Emmons, R. A., \& Paloutzian, R. F. (2003). The psychology of religion. Annual Review of Psychology, 54, 377-402. http://dx.doi.org/10.1146/annurev.psych.54.101601.145024

Emmons, R.A., McCullough, M.E. \& Tsang, J. (2007). The assessment of gratitude. In J.Lopez \& C. R. Snyder (Eds), Positive psychological assessment: A handbook of models and measures (pp.327-341). Washington DC: American Psychological Association.

Enright, R. D., \& Fitzgibbons, R. P. (2000). Helping clients forgive: An empirical guide for resolving anger and restoring hope. Washington, DC: American Psychological Association. http://dx.doi.org/10.1037/10381-000

Ergüner-Tekinalp, B., \& Terzi, Ş. (2012). Forgiveness as a therapeutic tool: Using forgiveness for healing in the counseling process. Education and Science, 37(166), 14-24.

Erözkan, A. (2004). The analysis of university student's interpersonal sensitiveness and rejection sensitiveness. [In Turkish]. Journal of Kırşehir Education Faculty (KEFAD), 5(2), 85-98.

Fourie, M. M., Gobodo-Madikizela, P., \& Stein, D. J. (2013). Empathy, forgiveness, and reconciliation: the truth and reconciliation commission in South Africa. In M. Linden \& K. Rutkowski (Eds.), Hurting Memories and Beneficial Forgetting, (pp. 227-237). Amsterdam: Elsevier. http://dx.doi.org/10.1016/B978-0-12-398393-0.00019-5

Fredrickson, B. L. (2004). Gratitude like other positive emotions broadens and builds. In R.A. Emmons, M.E. McCullough (Eds.), The psychology of gratitude, (pp. 145-166). New York: Oxford University Press. http://dx.doi.org/10.1093/acprof:oso/9780195150100.003.0008

Froh, J. J., Kashdan, T. B., Ozimkowski, K. M., \& Miller, N. (2009). Who benefits the most from a gratitude intervention in children and adolescents? Examining positive affect as a moderator. The Journal of Positive Psychology, 4, 408-422. http://dx.doi.org/10.1080/17439760902992464

Gable, S. L., \& Haidt, J. (2005). What (and why) is positive psychology? Review of General Psychology, 9(2), 103-110. http://dx.doi.org/10.1037/1089-2680.9.2.103

Gilbert, P., \& Procter, S. (2006). Compassionate mind training for people with high shame and self-criticism: Overview and pilot study of a group therapy approach. Clinical Psychology and Psychotherapy, 13, 353-379. http://dx.doi.org/10.1002/cpp.507

Gillham, J. E., \& Seligman, M. E. P. (1999). Footsteps on the road to positive psychology. Behaviour Research and Therapy, 37, 163-173. http://dx.doi.org/10.1016/S0005-7967(99)00055-8

Goei, R., \& Boster, F. J. (2005). The roles of obligation and gratitude in explaining the effect of favors on compliance. Communication Monographs, 72, 284-300. http://dx.doi.org/10.1080/03637750500206524

Gökçakan. Z., \& Gökçakan, N. (2005). Depresyonda bilişsel terapi. Mersin Üniversitesi Eğitim Fakültesi Dergisi, 1(1), 91-101.

Gudjonsson, G. H. (2010). Psychological vulnerabilities during police interviews. Why are they important? Legal and Criminological Psychology, 15, 161-175. http://dx.doi.org/10.1348/135532510X500064

Hall, J. H., \& Fincham, F. D. (2005). Self-forgiveness: The stepchild of forgiveness research. Journal of Social and Clinical Psychology, 24, 621-637. http://dx.doi.org/10.1521/jscp.2005.24.5.621

Hepp-Dax, S. H. (1996). Forgiveness as an educational goal with fifth-grade inner city children. ETD Collection for Fordham University. Paper AAI9708250.

Hoshi, M. (2008). Self-transcendence, vulnerability, and well-being in hospitalized Japanese elders. Ph.D., University of Arizona.

Howitt, D., \& Cramer, D. (2014). Introduction to statistics in psychology (6th ed.). Harlow, UK: Pearson.

Hu, L. T., \& Bentler, P. M. (1999). Cut off criteria for fit indexes in covariance structure analysis: Conventional criteria versus new alternatives. Structural Equation Modeling, 6, 1-55. 
The predictor role of gratitude and psychological vulnerability on forgiveness

http://dx.doi.org/10.1080/10705519909540118

Huta, V., \& Hawley, L. (2010). Psychological strengths and cognitive vulnerabilities: Are they two ends of the same continuum or do they have independent relationships with well-being and ill-being. Journal of Happiness Studies, 11, 71-93. http://dx.doi.org/10.1007/s10902-008-9123-4

Ingram, R. E., \& Luxton, D. D. (2005). Vulnerability-stress models. In B. L. Hankin \& J. R. Z. Abela (Eds.), Development of psychopathology: A vulnerability stress perspective (pp. 32-46). Thousand Oaks, CA: Sage Publications. http://dx.doi.org/10.4135/9781452231655.n2

Ingram, R. E., \& Price, J. M. (2010). Understanding psychopathology: the role of vulnerability. In R. E. Ingram \& J. M. Price (Eds.), Vulnerability to psychopathology: Risk across the lifespan (pp. 3-172). New York, NY: Guilford.

Kamat, V. L., Jones, W. H., \& Row, K. L. (2006). Assessing forgiveness as a dimension of personality. Individual Differences Research, 4, 322-330.

Karoly, P. (2010). Psychopathology as dysfunctional self-regulation: When resilience resources are compromised. In John W. Reich, Alex J. Zautra, \& John Stuart Hall (Eds), Handbook of adult resilience. New York: Guilford Press.

Kashdan, T. D., Uswatte, G., \& Julian, T. (2006). Gratitude and hedonic and eudaimonic well-being in Vietnam war veterans. Behaviour Research and Therapy, 44, 177-199. http://dx.doi.org/10.1016/j.brat.2005.01.005

Köse, S. (2003). A psychobiological model of temperament and character: TCI. Yeni Symposium, 41(2), 86-97.

Koutsos, P., Wertheim, E. H., \& Kornblum, J. (2008). Paths to interpersonal forgiveness: The roles of personality, disposition to forgive and contextual factors in predicting forgive-ness following a specific offence. Personality and Individual Differences, 44, 337-348. http://dx.doi.org/10.1016/j.paid.2007.08.011

Legaree, T. A., Turner, J., \& Lollis, S. (2007): Forgiveness and therapy: A critical review of conceptualizations, practices, and values found in the literature. Journal of Marital and Family Therapy, 33(2), 192-213. http://dx.doi.org/10.1111/j.1752-0606.2007.00016.x

Linley, P.A., \& Kauffman, C. (2007). Positive coaching psychology: Integrating the science of positive psychology with the practice of coaching psychology. International Coaching Psychology Review, 2(1), 5-8.

Lucas, T., Young, J. D., Zhdanova, L., \& Alexander, S. (2010). Self and other justice beliefs, impulsivity, rumination, and forgiveness: Justice beliefs can both prevent and promote forgiveness. Personality and Individual Differences, 49(8), 851-856. http://dx.doi.org/10.1016/j.paid.2010.07.014

Lyubomirsky, S., Sheldon, K. M., \& Schkade, D. (2005). Pursuing happiness: The architecture of sustainable change. Review of General Psychology, 9, 111-131. http://dx.doi.org/10.1037/1089-2680.9.2.111

Macaskill, A. (2012). Differentiating dispositional self-forgiveness from other-forgiveness: associations with mental health and life satisfaction. Journal of Social and Clinical Psychology, 31(1), 28-50. http://dx.doi.org/10.1521/jscp.2012.31.1.28

MacLachlan, A. (2012). Mercy and forgiveness. In Dan Callahan, Peter Singer, \& Ruth Chadwick (Eds.) Encyclopedia of Applied Ethics (2nd ed., pp. 113-120). San Diego: Academic Press. http://dx.doi.org/10.1016/B978-0-12-373932-2.00179-4

Madsen, S. R., Gygi, J., Hammond, S. C., \& Plowman, S. F. (2009). Forgiveness as a workplace intervention: The literature and a proposed framework. Journal of Behavioral and Applied Management, 10(2), 246-262.

Mayhew, S. L., \& Gilbert, P. (2008). Compassionate mind training with people who hear malevolent voices: A case series report. Clinical Psychology and Psychotherapy, 15, 113-138. http://dx.doi.org/10.1002/cpp.566

McCullough, M. E. (2008). Beyond revenge: The evolution of the forgiveness instinct. San Francisco: Jossey-Bass.

McCullough, M. E., \& Witvliet, C.V.O. (2001). The psychology of forgiveness. In C.R. Snyder and S. Lopez (Eds.), Handbook of Positive Psychology (pp. 446-458). New York: Oxford.

McCullough, M. E., Emmons, R. A., \& Tsang, J. A. (2002). The grateful disposition: A conceptual and empirical 
İlbay, A. B., \& Sarıçam, H.

topography. Journal of Personality and Social Psychology, 82, 112-127.

http://dx.doi.org/10.1037/0022-3514.82.1.112

McCullough, M. E., Kilpatrick, S. D., Emmons, R. A., \& Larson, D. B. (2001). Is gratitude a moral affect? Psychological Bulletin, 127, 249-266. http://dx.doi.org/10.1037/0033-2909.127.2.249

McCullough, M. E., Kimeldorf, M. B., \& Cohen, A. D. (2008). An adaptation for altruism? The social causes, social effects, and social evolution of gratitude. Current Directions in Psychological Science, 17, 281-284. http://dx.doi.org/10.1111/j.1467-8721.2008.00590.x

McLernon, F., Cairns, E., Hewstone, M., \& Smith, R. (2004). The development of intergroup forgiveness in Northern Ireland. Journal of Social Issues, 60, 587-601. http://dx.doi.org/10.1111/j.0022-4537.2004.00373.x

Miller, D. N., \& Nickerson, A. B. (2007). Changing the past, present, and future: Potential applications of positive psychology in school-based psychotherapy with children and youth. Journal of Applied School Psychology, 24(1), 147-162. http://dx.doi.org/10.1300/J370v24n01_08

Mongrain, M., \& Blackburn, S. (2005). Cognitive vulnerability, lifetime risk, and the recurrence of major depression in graduate students. Cognitive Therapy and Research, 29, 747-768. http://dx.doi.org/10.1007/s10608-005-4290-7

Monroe, S. M., \& Simons, A. D. (1991). Diathesis-stress theories in the context of life stress research: Implications for the depressive disorders. Psychological Bulletin, 110, 406-425. http://dx.doi.org/10.1037/0033-2909.110.3.406

Neff, K. D. (2011). Self-compassion, Self-esteem, and well-being. Social and Personality Psychology Compass, 5(1), 1-12. http://dx.doi.org/10.1111/j.1751-9004.2010.00330.x

North, J. (1987). Wrongdoing and forgiveness. Philosophy, 62, 499-508. http://dx.doi.org/10.1017/S003181910003905X

Nsamenang, S. A., Webb, J. R., Cukrowicz, K. C., \& Hirsch, J. K. (2013). Depressive symptoms and interpersonal needs as mediators of forgiveness and suicidal behavior among rural primary care patients. Journal of Affective Disorders, 149(1-3), 282-290. http://dx.doi.org/10.1016/j.jad.2013.01.042

Pearce, J. (1992). What can be done about the bully? In M. Elliot (Ed.) Bullying. A practical guide to coping for schools. Wiltshire: Longman.

Rafaeli, E., \& Hiller, A. (2010). Self-complexity: A source of resilience? In J. W. Reich, A. J. Zautra, \& J. S. Hall (Eds.), Handbook of adult resilience. New York: Guilford Press.

Riek, P. M. (2010). Transgressions, guilt, and forgiveness: A model of seeking forgiveness. Journal of Psychology and Theology, 38(4), 246-254.

Rungduin, D. C., \& Rungduin, T. T. (2013). The emergence of Filipino values among forgiveness studies. International Journal of Research Studies in Psychology, 4(2), 17-34. http://dx.doi.org/10.5861/ijrsp.2013.367

Sarıçam, H. (2015). The Turkish version of the Social Vulnerability Scale: The study of validity and reliability. International Online Journal of Educational Sciences, 7(1), 190-202. http://dx.doi.org/10.15345/iojes.2015.01.016

Sarıçam, H., \& Akın, A., (2012). The validity and reliability of the Turkish version of the Forgivingness Scale. Journal of Hasan Ali Yücel Faculty of Education, 19(2013-1), 37-46.

Satici, S. A., Uysal, R., \& Akin, A. (2014). Forgiveness and vengeance: The mediating role of gratitude. Psychological Reports, 114(1), 157-168. http://dx.doi.org/10.2466/07.09.PR0.114k11w9

Scanlon, A., \& Lee, G. (2007) The use of the terminacute care: Why does it differ and what does mean? Austrlian Journal of Advance Nursing, 24(3) 54-59.

Seligman, M. E. P. (2002). Positive Psychology, positive prevention and positive therapy. In (Ed: C. R. Snyder \& S. J. Lopez ), Handbook of positive psychology (pp. 3-9). NY: Oxford University Press.

Sheffield, C. J. (2003). An investigation of relationships between forgiveness, religiosity, religious coping, and psychological well-being. Unpublished Doctoral Dissertation. Brigham Young University, USA.

Silvers, J. A., Mcrae, K., Gabrieli, J. D. E., Gross, J. J., Remy, K. A., \& Ochsner, K. N. (2012). Age-related differences in emotional reactivity, regulation, and rejection sensitivity in adolescence. Emotion, 12(6), 
The predictor role of gratitude and psychological vulnerability on forgiveness

1235-1247. http://dx.doi.org/10.1037/a0028297

Sinclair, V. G., \& Wallston, K. A. (1999). The development and validation of the Psychological Vulnerability Scale. Cognitive Therapy and Research, 23(2), 119-129. http://dx.doi.org/10.1023/A:1018770926615

Southall, D., \& Roberts, J. E. (2002). Attributional style and self-esteem in vulnerability to adolescent depressive symptoms following life stress: A 14-week prospective study. Cognitive Therapy and Research, 26, 563-579. http://dx.doi.org/10.1023/A:1020457508320

Stamm, B. H. (1995). Introduction to the first edition. In B. Hudnall Stamm (Ed.), The secondary traumatic stress self-care issues for clinicians, researchers, educators. Brooklandville: Sidran Press.

Stevens, J. P. (2009). Applied multivariate statistics for the social sciences (5th ed.). New York: Routledge.

Strelan, P. (2007). Who forgive others, themselves and situations? The roles of narcissism, guilt, self-esteem and agreeableness. Personality and Individual Differences, 42, 259-269. http://dx.doi.org/10.1016/j.paid.2006.06.017

Tabachnick, B. G., \& Fidell, L. S. (2013). Using multivariate statistics (6th ed.). Boston: Pearson.

Taysi, E. (2007). Forgiveness in dyadic relationships: The role of relationship quality and attributions. [In Turkish]. Unpublished doctoral dissertation, Ankara University, Turkey.

Thompson, L. Y., \& Synder, C. R. (2003). Measuring forgiveness. In S. J. Lopez \& C. R. Snyder (Eds.), Positive psychological assessment: A handbook of models and measures (pp. 301-312). Washington, DC: American Psychological Association. http://dx.doi.org/10.1037/10612-019

Thoresen, C. E., Harris, A. H. S., \& Luskin, F. (2000). Forgiveness and Health: An unanswered question. In M. E. McCullough, K. I. Pargament, \& C. E. Thoresen (Eds.), Forgiveness: Theory, research and practice (pp. 254-280). New York: Guilford Press.

Tracy, J. L., Cheng, J. T., Robins, R. W., \& Trzesniewski, K. H. (2009). Authentic and hubristic pride: The affective core of self-esteem and narcissism. Self and Identity, 8, 196-213. http://dx.doi.org/10.1080/15298860802505053

Tse, W. S., \& Yip, T. H. J. (2009). Relationship among dispositional forgiveness of others, interpersonal adjustment and psychological well-being: Implication for interpersonal theory of depression. Personality and Individual Differences, 46(3), 365-368. http://dx.doi.org/10.1016/j.paid.2008.11.001

Wade, N., GBailey, D., \& Shaffer, P. (2005). Helping clients heal: Does forgiveness make a difference? Professional Psychology: Research and Practice, 36, 634-641. http://dx.doi.org/10.1037/0735-7028.36.6.634

Witvliet, C. V. O., Ludwig, T. E., \& Vander Laan, K. L. (2001). Granting forgiveness or harboring grudges: implications for emotion, physiology ,and health. Psychological Science, 12, 117-123. http://dx.doi.org/10.1111/1467-9280.00320

Wood, A. M., Froh, J. F., \& Geraghty, A. W. A. (2009). Gratitude and well-being: A review and theoretical integration. Clinical Psychology Review, 30(7), 890-905. http://dx.doi.org/10.1016/j.cpr.2010.03.005

Wood, A. M., Joseph, S., \& Maltby, J. (2009). Gratitude predicts psychological well-being above the big five facets. Personality and Individual Differences, 46, 443-447. http://dx.doi.org/10.1016/j.paid.2008.11.012

Woodyatt, L., \& Wenzel, M. (2013). Self-forgiveness and restoration of an offender following an interpersonal transgression. Journal of Social and Clinical Psychology, 32(2), 225-259. http://dx.doi.org/10.1521/jscp.2013.32.2.225

Worthington, E. L. (1997). The pyramid model of forgiveness. In Worthington E.L. (Ed.), Dimensions of forgiveness: Psychological research and theoretical perspective. PA: Templetion Foundation Press.

Worthington, E. L. (1998). An Empathy-humility-commitment model of forgiveness applied within family dyads. Journal of Family Therapy, 20, 59-76. http://dx.doi.org/10.1111/1467-6427.00068

Worthington, E. L., \& Wade, N. G. (1999). The social psychology of unforgiveness and forgiveness and implications for clinical practice. Journal of Social and Clinical Psychology, 18, 385-418. http://dx.doi.org/10.1521/jscp.1999.18.4.385

Worthington, E. L., Witvliet, C. V. O., Lerner, A. J., \& Scherer, M. (2005). Forgiveness in medical practice and research. The Journal of Science and Healing, 1, 169-176. 
İlbay, A. B., \& Sarıçam, H.

Wright, M. O., \& Masten, A. S. (2005). Resilience processes in development: fostering positive adaptation in the context of adversity. In S. Goldstein \& R. Brooks, (Eds), Handbook of resilience in children (pp. 17-37). Kluwer Academic/Plenum, New York, New York, USA. http://dx.doi.org/10.1007/0-306-48572-9_2

Yüksel, A., \& Oğuz Duran, N. (2012). Turkish adaptation of the Gratitude Questionnaire. Eurasian Journal of Educational Research, 46, 199-216. 